\title{
Concept of a New Technological System of a Biological Reactor in a Wastewater Treatment Plant in Nowy Targ in Terms of the Current Quantity and Quality of Wastewater - Case Study
}

\author{
Elwira Nowobilska-Majewska', Piotr Michał Bugajski ${ }^{*}$ \\ 1 Department of Sanitary Engineering and Water Management, University of Agriculture of Krakow \\ *Corresponding author's e-mail: p.bugajski@urk.edu.pl
}

\begin{abstract}
The objective of the work was to design a biological reactor in the Bardenpho system as an alternative to the SBR biological reactor in the wastewater treatment plant in Nowy Targ. The technological system of the newly designed biological reactor was adapted to the existing reinforced concrete structure. The design of individual nitrification, denitrification, predenitrification and dephosphatation chambers was developed on the basis of actual data on the volume of influent sewage and its pollutant loads. The newly designed technological system of the Bardenpho type biological reactor guarantees high efficiency in the elimination of organic and biogenic compounds from wastewater. Within operational guidelines, it is proposed to gradually eliminate the inflow of foreign waters to the sewage system by removing the illegally connected roof gutters. Moreover, it is recommended to strictly control the volume of the fur-plant industrial sewage discharged into the sewage system.
\end{abstract}

Keywords: Bardenpho bioreactor design, sewage volume, pollution load.

\section{INTRODUCTION}

The design of a newly built or modernized wastewater treatment plant involves complex activities at many stages, and wrong decisions made at the design stage will have a negative impact on the treatment processes during many years of the treatment plant operation (Takács 2008, Dymaczewski et al. 2011, Meriç et al. 2002, Karamus 2018). When designing a wastewater treatment plant, the first and most important step is to correctly determine the volume of influent wastewater and its quality, i.e. concentration of pollutants (Młyński et al. 2016, Kaczor 2020, Jóźwiakowska and Marzec 2020, Szeląg and Barbusiński 2020). Considering the fact that the operating wastewater treatment plants are frequently underloaded or hydraulically overloaded, the designer should take into account the local specificity of the volume of water use (sewage discharge) by residents when determining the hydraulic load, and not employ standard guidelines in this regard (Bergel 2017, Bergel and Młyńska 2021). Another factor that determines the hydraulic load in wastewater treatment plants is the uncontrolled inflow of incidental (rain) waters from gutter outlets illegally connected to the sewage network (Kaczor and Bugajski 2012, Kaczor et al. 2017). An equally important issue when designing a treatment plant is the proper determination of the pollutant load in raw sewage, i.e. in the sewage subjected to the treatment process. The pollutant load taken into account for the calculation of the biological reactor should reflect domestic sewage, sewage delivered from septic tanks, and industrial sewage from industrial plants (Nowobilska-Majewska 2017). Each of these types of wastewater is characterized by a different and highly varying concentration of pollutants (Kaczor 2009, Bugajski et al. 2017, Bugajski et al. 2020).

The objective of the work was to design the technological system of the Bardenpho type biological reactor as an alternative to the currently existing biological SBR in the wastewater treatment plant in Nowy Targ. The biological reactor was designed on the basis of the results from 
many years of research concerning the quantity and quality of wastewater flowing from the sewage system to the described treatment plant. In the wastewater treatment plant in Nowy Targ, there is a need to change the technology of the biological reactor in order to improve the biological treatment processes in terms of the current hydraulic load and the concentration of pollutants in the wastewater flowing from the sewage system.

\section{MATERIALS AND METHODS}

\section{Characteristics of the sewerage system}

The wastewater treatment plant in Nowy Targ was established in 1995 and is located at $49^{\circ} 29^{\prime} \mathrm{N}$, $20^{\circ} 3^{\prime} \mathrm{E}$. The technological system of the sewage treatment plant was designed for the average daily flow $\mathrm{Q}_{\text {sr.d. }}=21,000 \mathrm{~m}^{3} / \mathrm{d}$ and $\mathrm{PE}=116,000$ inhabitants. The wastewater from the municipal sewerage network is conveyed via a collector with a diameter $\mathrm{DN}=1.2 \mathrm{~m}$ to a pumping station. The main pumping station operates two pumps with a capacity of $1,400 \mathrm{~m}^{3} / \mathrm{h}$. The pumps lift sewage to a height of $7.5 \mathrm{~m}$ for easy gravity flow through the entire process line. The sewage flows from the pumping station to a screen room, where screenings are caught on two step-screens with a slot width of $3 \mathrm{~mm}$ and a rated power of $1.5 \mathrm{~kW}$.
The wastewater then flows into two sand traps, where mineral substances such as sand or gravel undergo sedimentation. The sand separated by sedimentation is discharged into a sand scrubber separator, and - after cleaning and dewatering - is fed into a container. The wastewater leaving the sand traps is conveyed by an $800 \mathrm{~mm}$ DN pipeline to two primary settling tanks. The horizontalflow settling tanks are $42.0 \mathrm{~m}$ long, $6.0 \mathrm{~m}$ wide and $3.6 \mathrm{~m}$ high. Primary sludge is collected in sludge hoppers and cyclically removed to a gravity thickener. Biological treatment is performed using the sequencing batch reactor method. In the biological treatment section, three bioreactors are installed, which work in 8-hour cycles. Each reactor is $70 \mathrm{~m}$ long, $23 \mathrm{~m}$ wide and $4.5 \mathrm{~m}$ deep. The treated wastewater, after decanting, is discharged through a $1000 \mathrm{~mm}$ DN collector pipe to the receiver, the Dunajec river. The location of the treatment plant in Nowy Targ is shown in Figure 1. The scheme of the actual technological layout of the wastewater treatment plant in Nowy Targ is shown in Figure 2.

\section{Characteristic volume of wastewater and of pollution indicators}

The average daily amount of inflowing sewage amounting to $Q_{\text {d.si }}=14,480.8 \mathrm{~m}^{3} / \mathrm{d}$, assumed as the reliable flow for the design, was determined

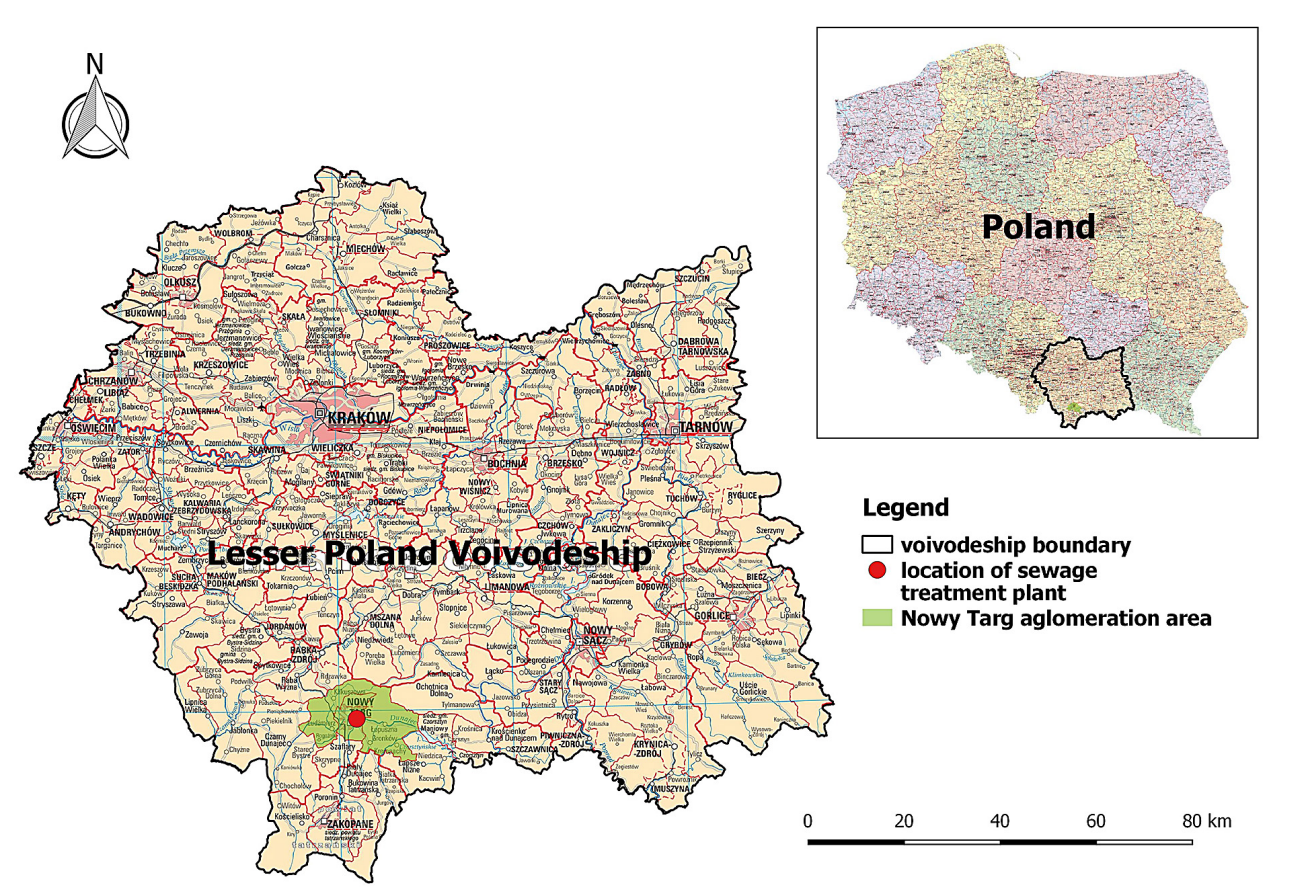

Figure 1. The location of the rural agglomeration of Nowy Targ against the background of the Lesser Poland Voivodeship and Poland (source: own study) 


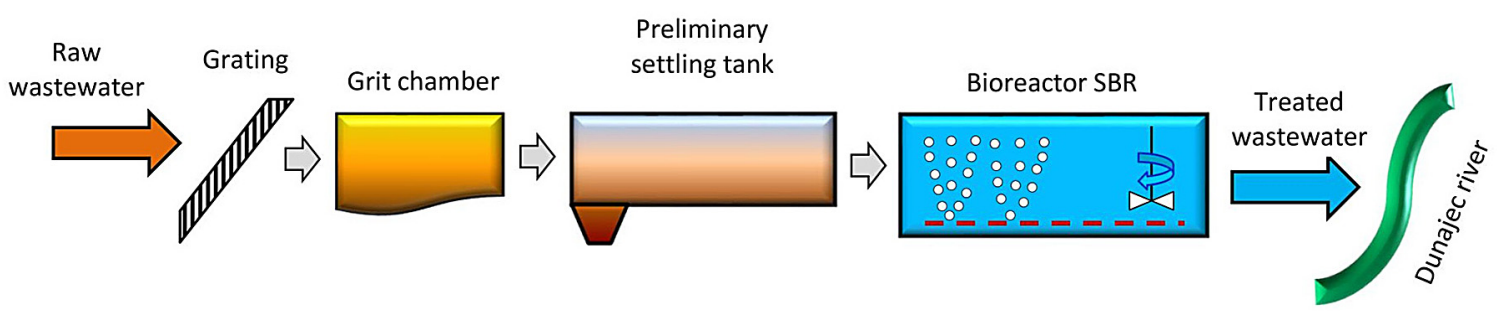

Figure 2. Scheme of the technological layout of the wastewater treatment plant in Nowy Targ: current situation

on the basis of reports in publications (Nowobilska-Majewska and Bugajski 2019a, NowobilskaMajewska 2020). The average daily representative flow taken into account in the design of the biological reactor is the resultant measure, i.e. the arithmetic mean for the years 2016-2017, where in 2016, the average daily inflow was $\mathrm{Q}_{\text {d.avg }}=13,963.9 \mathrm{~m}^{3} / \mathrm{d}$, and the average daily inflow in 2017 was $Q_{\text {d.sr }}=14,997.8 \mathrm{~m}^{3} / \mathrm{d}$. On the basis of the average daily wastewater inflow $\mathrm{Q}_{\mathrm{d} \text {.s. }}$ and the $\mathrm{BOD}_{5}$ content in raw sewage, the current Population Equivalent is $\mathrm{PE}=125,000$. Pursuant to the guidelines in the applicable Regulation, the wastewater treatment plant is included in the group of facilities over 100,000 PE (Journal of Laws of $15^{\text {th }}$ July 2009, item 1311). Reliable values of pollution indicators in raw sewage and in sewage after mechanical treatment were determined on the basis of information in publications (Nowobilska-Majewska and Bugajski 2019b, Bugajski and Nowobilska-Majewska 2019). The average values of the analysed pollution indicators in raw sewage (in sewage after mechanical treatment) are as follows:

- $\mathrm{BOD}_{5}-498.5(378.0) \mathrm{g} / \mathrm{m}^{3}$

- $C O D-1615.9(1027.3) \mathrm{g} / \mathrm{m}^{3}$

- $\mathrm{TSS}-1079.5(504,5) \mathrm{g} / \mathrm{m}^{3}$

- $\mathrm{TN}-106.6(72.9) \mathrm{g} / \mathrm{m}^{3}$

- $\mathrm{TP}-18.2(11.70) \mathrm{mg} / \mathrm{m}^{3}$

\section{RESULTS AND DISCUSSION}

This chapter presents the design of the technological system of the Bardenpho type biological reactor, taking into account the volume of treated wastewater as well as the concentration of organic and biogenic pollutants in the wastewater after the mechanical treatment stage. An important quality feature of the sewage flowing into the biological reactor is its biodegradability, which is expressed by the $\mathrm{BOD}_{5} / \mathrm{TN}$ and $\mathrm{BOD}_{5} / \mathrm{TP}$ relationships (Miksch and Sikora 2010, Młyńska et al. 2017, Suchowska-Kisielewicz et al. 2018).
In this case, in the wastewater after mechanical treatment, the $\mathrm{BOD}_{5} / \mathrm{TN}$ ratio was 5.2 , while the $\mathrm{BOD}_{5} / \mathrm{TP}$ ratio was 33.7. The results of the calculated quotients indicate that the sewage is susceptible to biological decomposition of nitrogen and phosphorus compounds. However, these are average values and, as shown in previous studies, there are periods in which the $\mathrm{BOD}_{5}$ value in the inflowing sewage decreases as a result of an excess of rainwater inflow to the sewage system, which means that their biodegradability also decreases (Nowobilska-Majewska E., Bugajski P. 2019b). In the period when the sewage flowing into the biological reactor loses its susceptibility to biodegradation, an additional source of organic carbon should be dosed, e.g. methanol, ethanol, acetic acid, lactic acid, sugar beet syrup, or starch. In addition, when the $\mathrm{BOD}_{5} / \mathrm{TP}$ ratio is not maintained, chemical support for phosphorus removal should be ensured through the use of PIX (e.g. iron sulphate $\mathrm{Fe}_{2}\left(\mathrm{SO}_{4}\right)_{3} \cdot 9 \mathrm{H}_{2} \mathrm{O}$ ). Bearing in mind that the sewage flowing into the biological reactor is susceptible to biological decomposition of nitrogen compounds and phosphorus compounds, calculations were performed for the removal of nitrogen compounds and phosphorus compounds. In the first stage, the concentration of ammonium nitrogen undergoing the nitrification process was calculated based on the formula (1) and the degree of nitrification based on the formula (2):

$$
\begin{gathered}
C_{\text {NIT }}=C_{\mathrm{TN}_{-} \mathrm{M}}-\mathrm{C}_{\text {Norg }}-\mathrm{C}_{\mathrm{NH} 4}-\mathrm{C}_{\mathrm{N}_{-} \mathrm{BM}} \\
\mathrm{C}_{\mathrm{NIT}}=52.0 \mathrm{~g} / \mathrm{m}^{3}
\end{gathered}
$$

where: $C_{N I T}-$ nitrified ammonium nitrogen concentrations $\left[\mathrm{g} / \mathrm{m}^{3}\right]$

$C_{\text {TN_M }}$ - concentration of total nitrogen in the sewage flowing to the biological reactor after mechanical treatment $-72.9 \mathrm{~g} / \mathrm{m}^{3}$, $C_{\text {Norg }}-$ organic nitrogen concentration in sewage flowing out of the biological reactor $-2.0 \mathrm{~g} / \mathrm{m}^{3}$, 
$\mathrm{C}_{\mathrm{NH} 4}$ - concentration of ammonium nitrogen in sewage flowing out of the biological reactor $-0.0 \mathrm{~g} / \mathrm{m}^{3}$, $C_{N_{-} B M}-$ organic nitrogen concentration in wastewater discharged from the biological reactor - (assumed $-5 \% \mathrm{BOD}_{5}$ in wastewater after mechanical treatment) $18.9 \mathrm{~g} / \mathrm{m}^{3}$

$$
\begin{array}{r}
\mathrm{y}_{\mathrm{NIT}}=\frac{\mathrm{C}_{\mathrm{NIT}}}{\mathrm{C}_{\mathrm{TN}} \mathrm{M}} \cdot 100 \\
\mathrm{I}_{\mathrm{NIT}}=71.3 \%
\end{array}
$$

where: $\eta_{\text {NIT }}$ - degree of ammonium nitrogen reduction in the nitrification process [\%]

The concentrations of nitrates subjected to denitrification were then calculated from the formula (3) and the degree of denitrification based on the formula (4):

$$
\begin{array}{r}
C_{D E N}=C_{N I T}-C_{N_{0} 3_{-} T} \\
C_{D E N}=43.0 \mathrm{~g} / \mathrm{m}^{3}
\end{array}
$$

where: $C_{D E N}-$ concentrations of nitrates undergoing denitrification $\left[\mathrm{g} / \mathrm{m}^{3}\right]$

$\mathrm{C}_{\mathrm{NO}_{3} \mathrm{~T}}-$ concentration of nitrate nitrogen in the treated sewage $-9 \mathrm{~g} / \mathrm{m}^{3}$

$$
\begin{array}{r}
\eta_{\text {DEN }}=\frac{C_{\text {DEN }}}{C_{\text {TN }} M} \cdot 100 \\
\eta_{\text {DEN }}=58.9 \%
\end{array}
$$

where: $\eta_{D E N}-$ degree of reduction of nitrates in the process of denitrification [\%]

On the basis of the information on the concentration of nitrates subjected to the denitrification process and the $\mathrm{BOD}_{5}$ value in the sewage flowing into the biological reactor, the denitrification potential was calculated (formula 5) to determine the volume of the denitrification chamber in relation to the total volume of the bioreactor.

$$
P_{\mathrm{DEN}}=\frac{\mathrm{C}_{\mathrm{DEN}}}{\mathrm{C}_{\mathrm{BOD} \mathrm{D}_{5} \mathrm{M}}}
$$

$$
\mathrm{P}_{\mathrm{DEN}}=0.11 \mathrm{kgNO}_{3} / \mathrm{kgBOD}_{5}
$$

where: $P_{D E N}-$ denitrification potential $\left[\mathrm{kgNO}_{3} /\right.$ $\mathrm{kgBOD}_{5}$ ]
$C_{\text {BOD5_M }}-\mathrm{BOD}_{5}$ in sewage after mechanical treatment $-378 \mathrm{~g} / \mathrm{m}^{3}$

On the basis of the PDEN denitrification potential and assuming that simultaneous denitrification occurs in the Bardenpho $V_{R}$ biological reactor, it was determined that the volume of the denitrification chamber would be $\mathrm{V}_{\mathrm{D}}=20 \%(0.2)$ and that of the nitrification chamber $\mathrm{V}_{\mathrm{N}}=80 \%$ (0.8).

The next stage of the design was to determine the Sludge Age (formula 6) and the amount of daily excess sludge increase $\Delta \mathrm{G}_{\mathrm{d}}$ (formula 7).

$$
\begin{gathered}
W O=\frac{S F \cdot 3.4 \cdot 1.103^{15-T}}{1-V_{D}} \\
W O=12.5 \mathrm{~d}
\end{gathered}
$$

where: $W O$ - sludge age [d]

$T$ - wastewater temperature in the biological reactor - adopted at $10^{\circ} \mathrm{C}$

$S F$ - safety factor for nitrification - adopted $1.8[-]$

$$
\begin{aligned}
\Delta \mathrm{G}_{\mathrm{d}} & =\Delta \mathrm{G} \cdot \mathrm{E}_{\mathrm{U}_{-} \text {BOD }} \\
\Delta \mathrm{G}_{\mathrm{d}} & =5782.3 \mathrm{~kg} \mathrm{~d} . \mathrm{m} . / \mathrm{d}
\end{aligned}
$$

where: $\Delta G_{d}-$ daily excess sludge increase $[\mathrm{kg}$ $\mathrm{dm} / \mathrm{d}]$

$\Delta G$ - unit increment of excess sludge $[\mathrm{kg}$ d.m. $/ \mathrm{kg} \mathrm{BOD}{ }_{5}$ - adopted at $1.1 \mathrm{~kg} \mathrm{NO}_{3}$ $\mathrm{kg} \mathrm{BOD}{ }_{5}$

$士_{U-B O D 5}-$ load of the removed $\mathrm{BOD}_{5}[\mathrm{~kg}$ d.m. $/ \mathrm{kg} \mathrm{BOD}{ }_{5}$ ] - calculated from the formula (8):

$$
\begin{aligned}
& \mathrm{E}_{\mathrm{U}_{-} \mathrm{BOD} 5}=\mathrm{Q}_{\mathrm{d} . \mathrm{s}_{\mathrm{r} .}} \cdot\left(\mathrm{C}_{\mathrm{BOD} 5_{\mathrm{M}}}-\mathrm{C}_{\mathrm{BOD} 5_{0}}\right) \cdot 10^{-3} \\
& \mathrm{E}_{\mathrm{U}_{-} \text {BOD } 5}=5256.6 \mathrm{~kg} \mathrm{~d} . \mathrm{m} \cdot / \mathrm{kgBOD}
\end{aligned}
$$

where: $Q_{d . s . r}-$ average daily sewage inflow $14,480.8 \mathrm{~m}^{3} / \mathrm{d}$

$C_{\text {BOD5_M }}-\mathrm{BOD}_{5}$ in sewage after mechanical treatment $-378 \mathrm{~g} / \mathrm{m}^{3}$

$C_{\text {BOD5O }}-\mathrm{BOD}_{5}$ in treated sewage - adopted $15 \mathrm{~g} / \mathrm{m}^{3}$ as the limit value for treatment plants above 100,000 PE (Journal of Laws of $15^{\text {th }}$ July 2019 , item 1311)

In order to determine the amount of nonbiodegradable phosphorus intended for chemical precipitation, the formula (9) was used: 


$$
\begin{gathered}
\mathrm{C}_{\mathrm{TP}_{-} \mathrm{CHEM}}= \\
=\mathrm{C}_{\mathrm{TP}_{-} \mathrm{M}}-\mathrm{C}_{\mathrm{TP}_{-} \mathrm{DEF}}-\mathrm{C}_{\mathrm{TP}_{-} \mathrm{BM}}-\mathrm{C}_{\mathrm{TP}_{-} \mathrm{O}} \\
\mathrm{C}_{\mathrm{TP}_{-} \mathrm{CHEM}}=2.1 \mathrm{~g} / \mathrm{m}^{3}
\end{gathered}
$$

where: $C_{\text {TP_CHEM }}-$ concentration of phosphorus intended for chemical precipitation $\left[\mathrm{g} / \mathrm{m}^{3}\right]$ $C_{\text {TP_M }}$ - concentration of phosphorus flowing into the biological reactor after mechanical treatment $-11.7 \mathrm{~g} / \mathrm{m}^{3}$

$C_{\text {TP_DEF }}$ - reduced phosphorus concentration in the dephosphatation process (assumed $1 \% \mathrm{BOD}_{5}$ in the sewage after mechanical treatment) $-3.8 \mathrm{~g} / \mathrm{m}^{3}$

$C_{\text {TP_BM }}$ - concentration of phosphorus embedded in biomass (assumed 1\% $\mathrm{BOD}_{5}$ in sewage after mechanical treatment) $3.8 \mathrm{~g} / \mathrm{m}^{3}$

$C_{T P \_}-$phosphorus concentration in the treated sewage - assumed $2.0 \mathrm{~g} / \mathrm{m}^{3}$

It is proposed to use the PIX-113 coagulant for phosphorus precipitation (with the content of $11.8 \% \mathrm{Fe}$ and the density $\mathrm{gK}=1500 \mathrm{~kg} / \mathrm{m}^{3}$ ). The $\mathrm{D}_{\mathrm{K}}$ dose was calculated from the formula (10):

$$
\begin{aligned}
\mathrm{D}_{\mathrm{K}} & =\frac{2.7 \cdot \mathrm{C}_{\mathrm{TP}} \mathrm{CHEM}}{0.118} \\
\mathrm{D}_{\mathrm{K}} & =48.1 \mathrm{gFe} / \mathrm{m}^{3}
\end{aligned}
$$

On the basis of the knowledge of the concentration of individual indicators of pollutants flowing into the biological reactor and the kinetics of nitrification, denitrification and dephosphatation processes, the dimensions of the Bardenpho biological rector were calculated taking into account the existing design of SBRs. In the biological part of the analysed wastewater treatment plant in Nowy Targ, there are 3 biological reactors with the following dimensions: length $\mathrm{L}=70 \mathrm{~m}$, width $\mathrm{B}=23 \mathrm{~m}$, and active depth $\mathrm{H}=4.5 \mathrm{~m}$.

In the first stage, the total $V_{R}$ volume of the nitrification and denitrification chambers was determined (formula 11):

$$
\begin{aligned}
V_{R} & =\frac{w o \cdot \Delta G_{d}}{C_{G}} \\
V_{R} & =19534.8 \mathrm{~m}^{3}
\end{aligned}
$$

where: $C_{g}$ - activated sludge concentration in the reactor - assumed $3.7 \mathrm{~g} \mathrm{dm} / \mathrm{m}^{3}$
In order to calculate the volume of the $\mathrm{V}_{\mathrm{R}}$ bioreactor, the optimal concentration of the dry mass of the sediment $\mathrm{C}_{\mathrm{g}}$ was assumed based on the results of the calculations by NowobilskaMajewska and Bugajski (2020).

As there are 3 chambers in the current technological system of the biological SBR, also in the newly designed Bardenpho reactor, the total volume of $V_{R}$ was divided into 3 segments (formula 12).

$$
\begin{gathered}
V_{R 1}=\frac{V_{R}}{3} \\
V_{R 1}=6511.6 \mathrm{~m}^{3}
\end{gathered}
$$

On the basis of the volume of a single $V_{R 1}$ segment and the already existing structure with the dimensions of $\mathrm{L}=70 \mathrm{~m}$ and $\mathrm{B}=23 \mathrm{~m}$, it was found that the dimensions of the designed single segment should be (13):

$$
\mathrm{L} \cdot \mathrm{B} \cdot \mathrm{H}=\mathrm{V}_{\mathrm{R} 1}
$$

The dimensions of a single segment should be:

- Length $\mathrm{L}=70 \mathrm{~m}$

- Width $B=23 \mathrm{~m}$

- Usable depth $\mathrm{H}=4.05 \mathrm{~m}$

The biological rector in Bardenpho technology will consist of 3 segments with nitrification and denitrification (anoxic) chambers and additionally a dephosphation chamber and a predenitrification chamber.

On the basis of the determined volume of the (anoxic) denitrification chamber $\mathrm{V}_{\mathrm{D}}=20 \%(0.2)$ and the volume of the nitrification chamber $\mathrm{V}_{\mathrm{N}}$ $=80 \%(0.8)$, the dimensions of these chambers were calculated from the formulas (14) and (15):

$$
\begin{array}{r}
\mathrm{L}_{\mathrm{DEN}}=0.2 \cdot \mathrm{L} \\
\mathrm{L}_{\mathrm{DEN}}=14 \mathrm{~m} \\
\mathrm{~L}_{\mathrm{NIT}}=0.8 \cdot \mathrm{L} \\
\mathrm{L}_{\mathrm{NIT}}=56 \mathrm{~m}
\end{array}
$$

where:

$L_{D E N}$ - length of denitrification (anoxic) chamber [m]

$L_{N I T}-$ length of the nitrification chamber [m] 
The volume of the $\mathrm{V}_{\mathrm{DEF}}$ dephosphation chamber and the $\mathrm{V}_{\text {PRE }}$ predenitrification chamber were calculated from the formulas (16) and (17):

$$
\begin{gathered}
\mathrm{V}_{\mathrm{DEF}}=\frac{\mathrm{Q}_{\text {d.́s. }}}{24} \cdot \mathrm{t}_{\mathrm{Z} 1} \\
\mathrm{~V}_{\mathrm{DEF}}=905.1 \mathrm{~m}^{3} \\
\mathrm{~V}_{\mathrm{PRE}}=\frac{\mathrm{Q}_{\text {d.śr. }}}{24} \cdot \mathrm{t}_{\mathrm{Z} 2} \\
\mathrm{~V}_{\mathrm{PRE}}=603.4 \mathrm{~m}^{3}
\end{gathered}
$$

where: $Q_{d . s ́ r}-$ average daily sewage inflow $14,480.8 \mathrm{~m}^{3} / \mathrm{d}$

$T_{Z 1}$ - time of wastewater retention in the dephosphatation chamber $-1.5 \mathrm{~h}$

$T_{Z 2}$ - time of wastewater retention in the predenitrification chamber $-1.0 \mathrm{~h}$

The dimensions of the dephosphation and predenitrification chambers were determined on the basis of their area $\mathrm{F}_{\mathrm{DEF}}$ (formula 18) and $\mathrm{F}_{\mathrm{PRE}}$ (formula 19), and then their widths and lengths were calculated.

$$
\begin{aligned}
& F_{D E F}=\frac{v_{D E F}}{H} \\
& F_{D E F}=223.5 \mathrm{~m}^{2} \\
& F_{P R E}=\frac{v_{P R E}}{H} \\
& F_{P R E}=148.9 \mathrm{~m}^{2}
\end{aligned}
$$

where: $H$ - usable depth - set at $4.05 \mathrm{~m}$

It was assumed that the total length of the dephosphation $\left(\mathrm{L}_{\mathrm{DEF}}\right)$ and predenitrification $\left(\mathrm{L}_{\mathrm{PRE}}\right)$ chambers should be $69 \mathrm{~m}$, i.e. the total width for 3 segments ( $3 \times \mathrm{B})$.

The assumptions for calculating the dimensions of the dephosphation and predenitrification chamber were as follows:

$$
\begin{gathered}
\mathrm{L}_{\mathrm{DEF}}+\mathrm{L}_{\mathrm{PRE}}=3 \cdot \mathrm{B}=69 \mathrm{~m} \\
\mathrm{~L}_{\mathrm{DEF}} \cdot \mathrm{B}_{1}=\mathrm{F}_{\mathrm{DEF}} \rightarrow \mathrm{B}_{1}=5.8 \mathrm{~m} \\
\mathrm{~L}_{\mathrm{PRE}} \cdot \mathrm{B}_{1}=\mathrm{F}_{\mathrm{PRE}}
\end{gathered}
$$

where: $B_{1}$ - width of the dephosphatation chamber and predenitrification chamber [m]
Calculating the length of the dephosphation chamber $\left(\mathrm{L}_{\mathrm{DEF}}\right)$ - formula (20) and the length of the predenitrification chamber $\left(\mathrm{L}_{\mathrm{PRE}}\right)$ - formula (21):

$$
\begin{array}{r}
\mathrm{L}_{\mathrm{DEF}}=\frac{3 \cdot \mathrm{B} \cdot \mathrm{F}_{\mathrm{DEF}}}{\mathrm{F}_{\mathrm{DEF}}+\mathrm{F}_{\mathrm{PRE}}} \\
\mathrm{L}_{\mathrm{DEF}}=41.4 \mathrm{~m} \\
\mathrm{~L}_{\mathrm{PRE}}=3 \cdot \mathrm{B}-\mathrm{L}_{\mathrm{DEF}} \\
\mathrm{L}_{\mathrm{PRE}}=27.6 \mathrm{~m}
\end{array}
$$

On the basis of the prepared calculations and taking into account the current dimensions of the reactor structure, the total dimensions of the Bardenpho type biological reactor should be:

- Length: $\mathrm{L}_{\mathrm{C}}=\mathrm{L}_{\mathrm{NIT}}+\mathrm{L}_{\mathrm{DEN}}+\mathrm{B}_{1}=75.8 \mathrm{~m}$

- Width: $\mathrm{B}_{\mathrm{C}}=3 \cdot \mathrm{B}=69.0 \mathrm{~m}$

- Depth; $\mathrm{H}=4.05 \mathrm{~m}$

The diagram of the designed 3-segment Bardenpho-type biological reactor is shown in Figure 3. The new proposed technological system of the wastewater treatment plant with the Bardenpho-type reactor is shown in Figure 4.

\section{CONCLUSIONS}

The newly designed technological system of the Bardenpho type biological reactor is a system that guarantees high efficiency in the elimination of organic compounds $\left(\mathrm{BOD}_{5}\right.$ and $\left.\mathrm{COD}\right)$ and biogenic compounds (nitrogen and phosphorus) from wastewater after an initial mechanical treatment process. It is proposed to use a variable age of the sludge (WO) during the operation period and thus a variable amount of recirculated sludge from the secondary settling tank depending on the changes in the temperature of sewage in the bioreactor. The biological reactor was designed for the average daily sewage inflow, which is real and current. In order to avoid the hydraulic overload of the bioreactor during the operation period, it is necessary to eliminate or minimize the inflow of incidental (rain) waters, which are introduced into the sewage system in Nowy Targ. In addition, the amount of industrial wastewater from fur-plants entering the sewage system should be strictly controlled, because this wastewater contains significant amounts of chromium compounds, which is a toxic compound and reduces the metabolism of activated sludge microorganisms. 


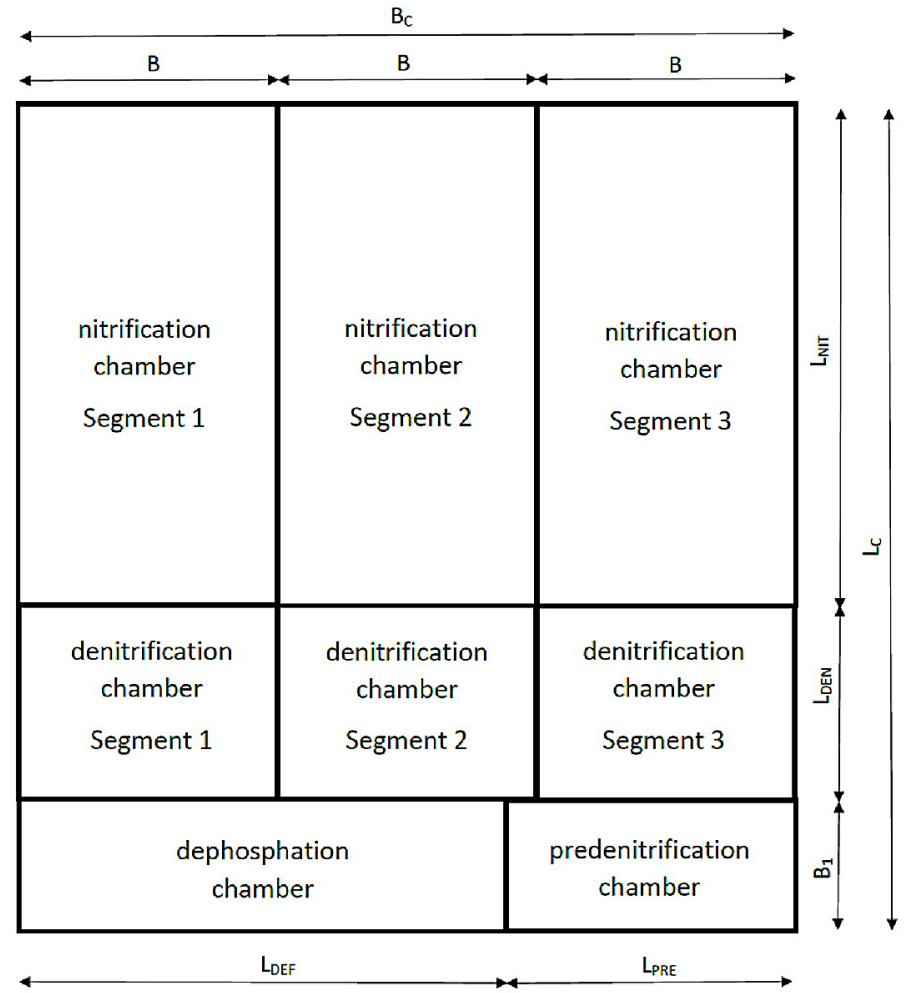

Figure 3. Bardenpho type biological reactor design

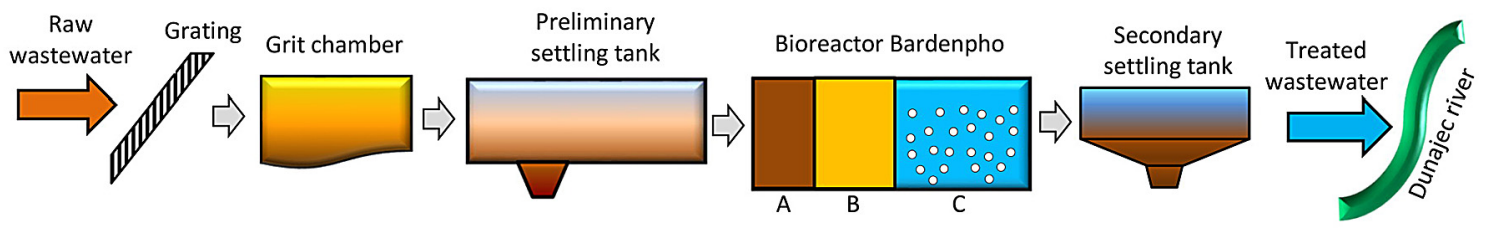

Figure 4. Scheme of the technological layout of the wastewater treatment plant in Nowy Targ - the design with the Bardenpho reactor ( $\mathrm{A}$ - anaerobic chamber, $\mathrm{B}$ - anoxic chamber, $\mathrm{C}$ - aerobic chamber)

\section{REFERENCES}

1. Bergel T. 2017. Practical implication of tap water consumption structure in rural households. Journal of Ecological Engineering, 18(1), 231-237.

2. Bergel T., Młyńska A. 2021. Analysis of the Impact of the Air Temperature on Water Consumption for Household Purposes in Rural Households. Journal of Ecological Engineering, 22(3), 289-302.

3. Bugajski P., Nowobilska-Majewska, E., Kurek K. 2017. The variability of pollution load of organic, biogenic and chromium ions in wastewater inflow to the treatment plant in Nowy Targ. Journal of Water and Land Development, 35(X-XII), 11-17.

4. Bugajski P., Nowobilska-Majewska E. 2019. A Weibull Analysis of the Reliability of a Wastewater Treatment Plant in Nowy Targ, Poland. Rocznik Ochrony Środowiska, 21, 825-840.
5. Bugajski P., Operacz A., Młyński D., Wałęga A., Kurek K. 2020. Optimizing Treatment of Cesspool Wastewater at an Activated Sludge Plant. Sustainability, 12, 10196;

6. Dymaczewski i in. 2011. The Manual for Operators of Wastewater Treatment Plant. PZITS o/Wielkopolski, Poznań 2011 (in Polish).

7. Jóźwiakowska K., Marzec M. Efficiency and reliability of sewage purification in long-term exploitation of the municipal wastewater treatment plant with activated sludge and hydroponic system. Arch. Environ. Prot., 46(3) 2020 30-41.

8. Kaczor G. 2009. Concentrations of the pollutants in the sewage drained from the rural sewerage systems in lesser Poland voivodeship. Infrastruktura $\mathrm{i}$ Ekologia Terenów Wiejskich, 9, 97-104 (in Polish).

9. Kaczor, G., Bugajski, P. 2012. Impact of Snowmelt Inflow on Temperature of Sewage Discharged to 
Treatment Plants. Polish Journal Environmental Studies, 21, 381-386.

10. Kaczor, G., Chmielowski, K., Bugajski, P. 2017. The effect of total annual precipitation on the volume of accidental water entering sanitary sewage system. Rocznik Ochrona Środowiska. 19, 668-681 (in Polish).

11. Kaczor G. 2020. Changes in concentrations and loads of total phosphorus in domestic and treated wastewater over a 15-year observation period in terms of limiting negative anthropopressure on the quality of surface water - case study. Acta Sci. Pol. For. Circum. 19 (2), 3-14.

12. Karamus Ł. 2018. Wastewater treatment plants and their exploitation. Wydawnictwo Kabe, ISBN: 978-83-65382-19-1, 232 (In Polish).

13. Meriç S., Kaptan D., Övez S., Okten H. E. 2002. Operational problems in small wastewater treatment plants: a case study. Fresenius Environmental Bulletin, 11(10b), 910-914.

14. Młyński D., Chmielowski K., Młyńska A. 2016. Analysis of hydraulic load of a wastewater treatment plant in Jasło. J. Water Land Develop. 28 (IIII), 61-67.

15. Miksch K., Sikora J. 2010. Wastewater biotechnology. Wydawnictwo Naukowe PWN, Warszawa (in Polish).

16. Nowobilska-Majewska E. 2017. Analysis of variability of chrome ion concentration in wastewater inflowing to the collective treatment plant in Nowy Targ. Ecol. Eng., 18 30-35 (in Polish).

17. Nowobilska-Majewska E., Bugajski P. 2019a. Influence of the amount of inflowing wastewater on concentrations of pollutions contained in the wastewater in the Nowy Targ sewerage system. E3S Web of Conferences 86, 00024 (2019). Ecological and Environmental Engineering 2018.

18. Nowobilska-Majewska E., Bugajski P. 2019b. The Analysis of the Amount of Pollutants in Wastewater after Mechanical Treatment in the Aspect of their Susceptibility to Biodegradation in the Treatment Plant in Nowy Targ. Journal of Ecological Engineering, 20(8), 135-143.

19. Nowobilska-Majewska E., Kotowski T., Bugajski P. 2020. Impact of atmospheric precipitation on the volume of wastewater inflowing to the treatment plant in Nowy Targ. E3S Web of Conferences 171, 01009 (2020).

20. Nowobilska-Majewska E., Bugajski P. 2020. The Impact of Selected Parameters on the Condition of Activated Sludge in a Biologic Reactor in the Treatment Plant in Nowy Targ, Poland. Water, 12, 2657.

21. Polish standards according limits for discharged sewage and environmental protection from July 12 (Dz. U. z dnia 15 lipca 2019, poz. 1311) (In Polish).

22. Suchowska-Kisielewicz M., Sieciechowicz A., Sadecka Z. 2018. The efficiency of nitrogen compounds removal in wastewater treatment plant. Civil and Environmental Engineering Reports. 28 (3): 005-016.

23. Szeląg, B., Barbusiński, K. 2020. Impact of the selected indicators of the wastewater quality and operating parameters of the biological reactor on the simulation of sludge sedimentation: Probabilistic approach. Desalination and Water Treatment, 186, 144-154.

24. Takács, I. 2008. Experiments in Activated Sludge Modeling. Ph.D. Thesis, Ghent University, Ghent, Belgium, 267. 